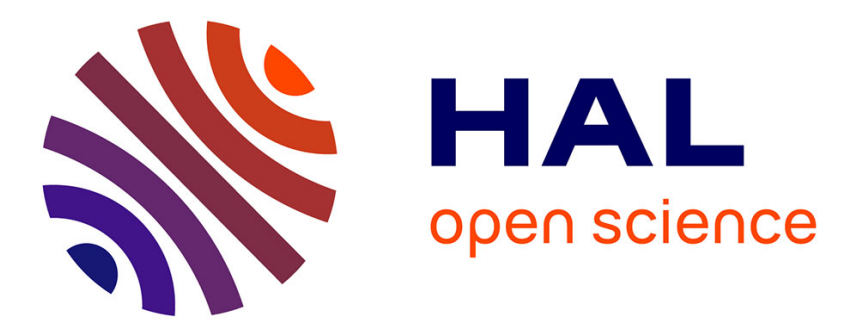

\title{
endophthalmitis with retinal involvement and infiltrative keratitis: case report and review of the literature
}

M. A. Horstkotte, S. Dobinsky, H. Rohde, J. K.-M. Knobloch, A. Hassenstein, M. Kalitzky, G. Richard, S. J. Linke

\section{- To cite this version:}

M. A. Horstkotte, S. Dobinsky, H. Rohde, J. K.-M. Knobloch, A. Hassenstein, et al.. endophthalmitis with retinal involvement and infiltrative keratitis: case report and review of the literature. European Journal of Clinical Microbiology and Infectious Diseases, 2010, 29 (6), pp.727-731. 10.1007/s10096010-0901-7 . hal-00587979

\section{HAL Id: hal-00587979 \\ https://hal.science/hal-00587979}

Submitted on 22 Apr 2011

HAL is a multi-disciplinary open access archive for the deposit and dissemination of scientific research documents, whether they are published or not. The documents may come from teaching and research institutions in France or abroad, or from public or private research centers.
L'archive ouverte pluridisciplinaire HAL, est destinée au dépôt et à la diffusion de documents scientifiques de niveau recherche, publiés ou non, émanant des établissements d'enseignement et de recherche français ou étrangers, des laboratoires publics ou privés. 
Diseases

Editorial Manager(tm) for European Journal of Clinical Microbiology \& Infectious

Manuscript Draft

Manuscript Number: EJCMID-D-09-00450R1

Title: Abiotrophia defectiva endophthalmitis with retinal involvement and infiltrative keratitis - Case report and review of the literature

Article Type: Brief Report

Keywords: Acute-onset postoperative endophthalmitis; retinal involvement; cataract surgery; Abiotrophia defectiva; nutritionally variant streptococci; $16 \mathrm{~S}$ ribosomal RNA gene sequencing

Corresponding Author: Dr. Matthias A. Horstkotte, M.D.

Corresponding Author's Institution: Bioscientia MVZ Hmburg

First Author: Matthias A Horstkotte, M.D.

Order of Authors: Matthias A Horstkotte, M.D.; Sabine Dobinsky; Holger Rohde; Johannes Knobloch; Andrea Hassenstein; Matthias Kalitzky; Gisbert Richard; Stephan J Linke

Abstract: We report the exceptional case of a severe intraocular Abiotrophia defectiva infection which developed after cataract surgery. Retinal involvement as a complication of A. defectiva endophthalmitis or the combination of acute-onset endophthalmitis with infiltrative keratitis caused by this pathogen has not been described. Moreover, our report represents the first documented ocular A. defectiva infection in Germany. A. defectiva was identified using biotyping and 16S ribosomal RNA gene sequence analysis. Despite vigorous antimicrobial therapy and repeated ocular surgery visual outcome was poor. 

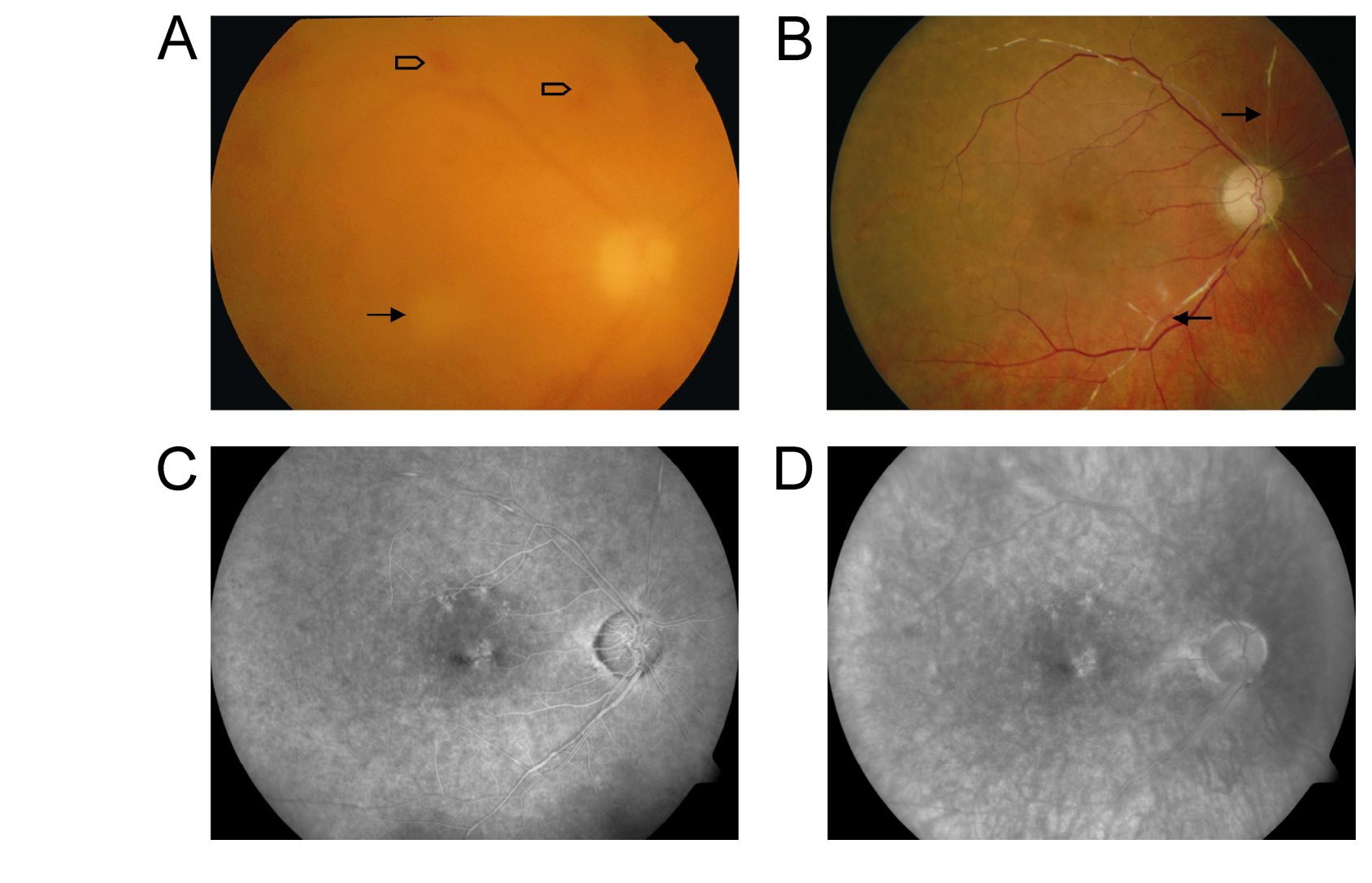

Figure
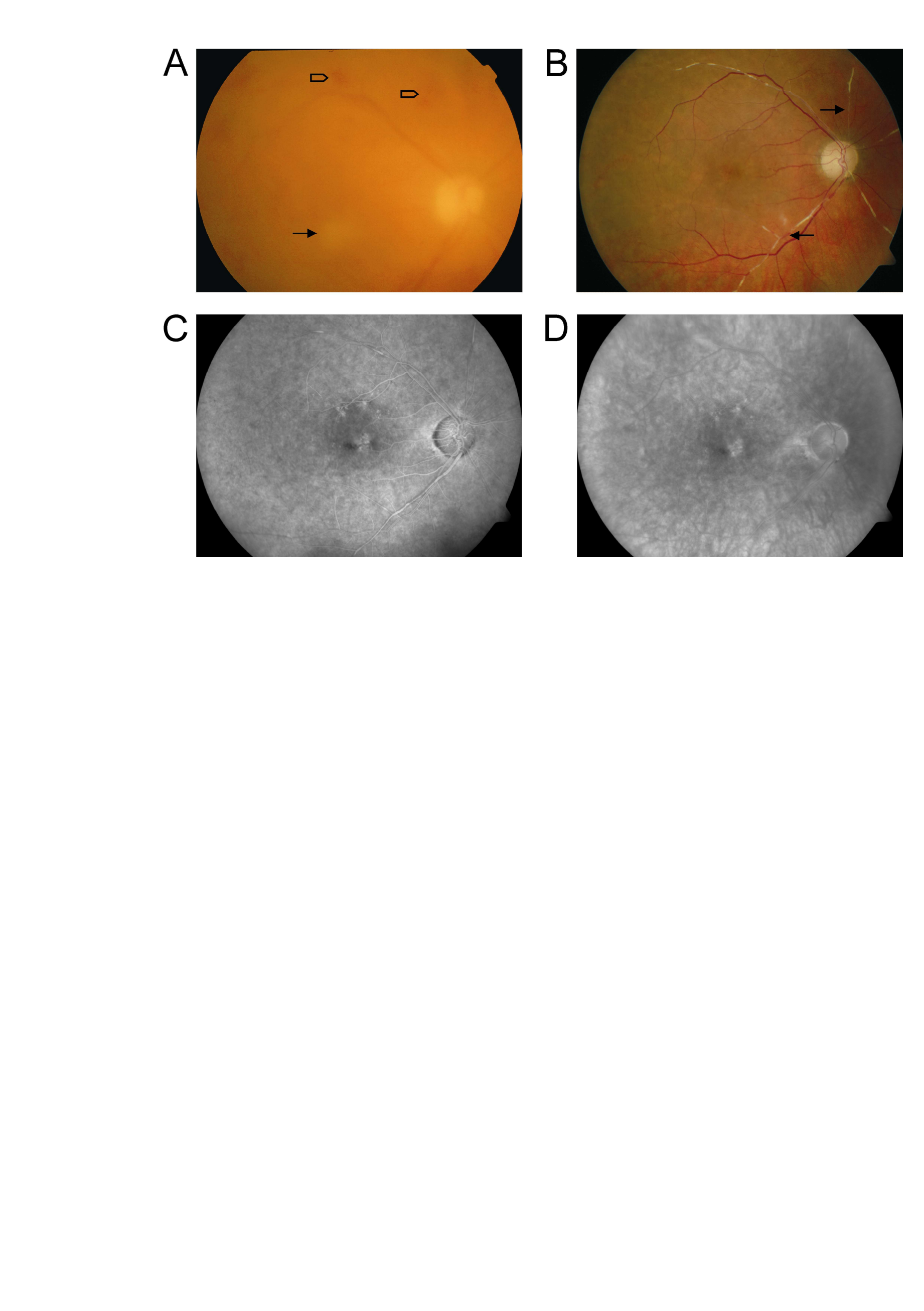

ran

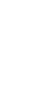

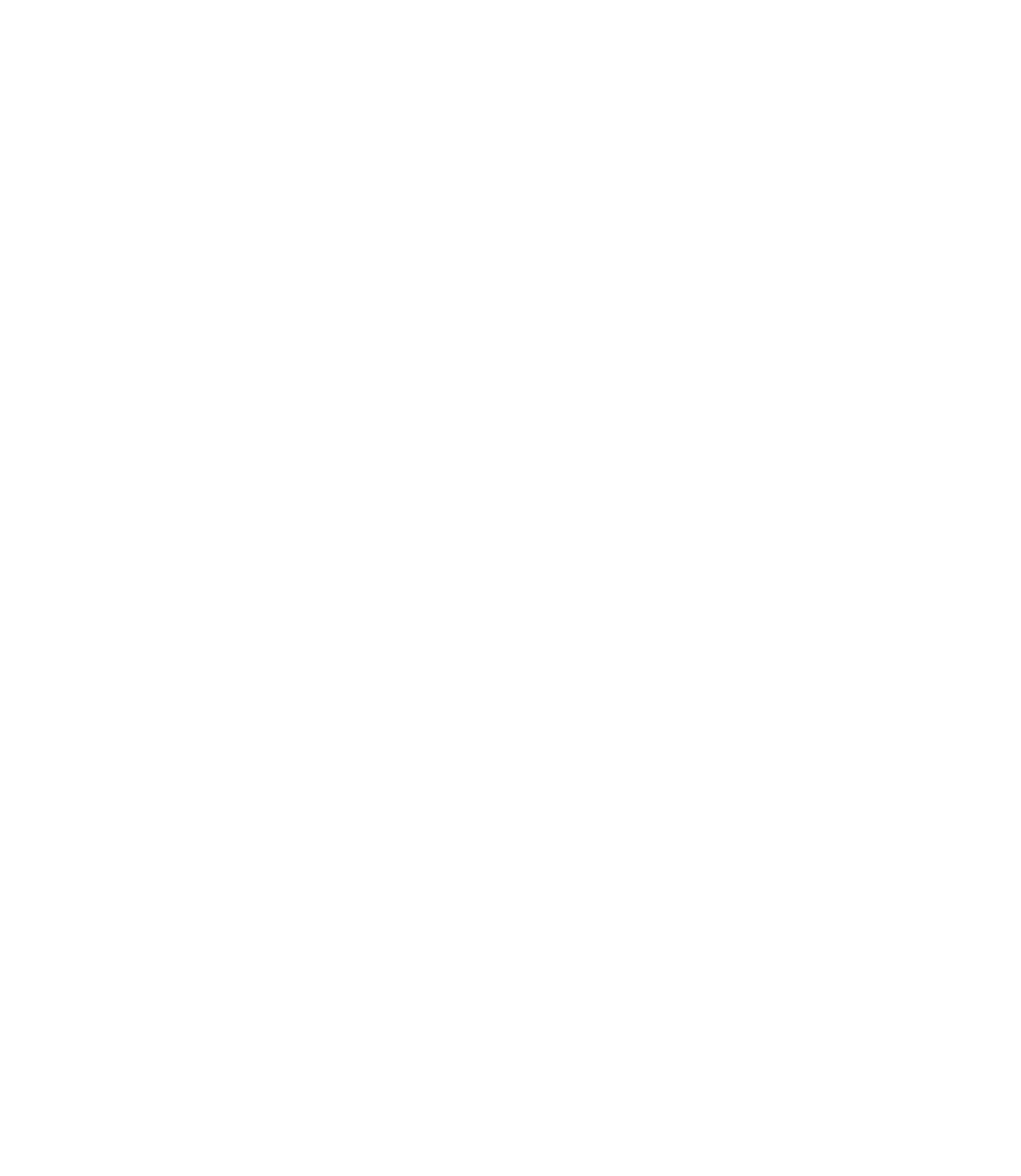




\author{
Dr. med. Matthias A. Horstkotte \\ Dr. von Froreich - Bioscientia \\ Medizinisches Labor \\ Großmoorbogen 25 \\ 21079 Hamburg \\ Telefon: $040-76696-117$ \\ Telefax: 040 - $76696-118$ \\ E-mail: hor@labor-froreich.de
}

$6^{\text {th }}$ January 2010

Dear Professor Dr. van Belkum, enclosed please find the revised manuscript "Abiotrophia defectiva endophthalmitis with retinal involvement and infiltrative keratitis - Case report and review of the literature" by Matthias A. Horstkotte, Sabine Dobinsky, Holger Rohde, Johannes K.-M. Knobloch, Andrea Hassenstein, Matthias Kalitzky, Gisbert Richard, and Stephan J. Linke, which has been reviewed with the manuscript number Ms. No. EJCMID-D-09-00450.

The suggestions of the reviewer have been entirely followed:

1. In the introduction line 7 the term sepsis has been replaced by the term septicemia

2. In the case report line 19 the term recurred has been replaced by the term relapsed.

3. The suggestion to describe the BLAST DATA in more detail was followed and the maximal nucleotide identity (Maxscore) and the difference to the next best taxon match is now included in the case report on page 5 . 
4. In the discussion line 20 the requested reference has been included. As the publication of Higgins R, Biberstein EL, and SS Jang (1984) Nutritionally variant streptococci from corneal ulcers in horses JCM 6, 1130-1134 is cited in reference 16 (Ormerod et al.) and to avoid adding another reference we decided to included the latter one.

We hope we have met the criticism of the reviewer and have improved our manuscript so that it can now be accepted for publication in the European Journal of Clinical Microbiology and Infectious Diseases.

Please acknowledge the receipt of the revised manuscript. If convenient for you, please use our Fax: + 49 40/766 96118 or E-mail: hor@ labor-froreich.de

Yours sincerely

Dr. Matthias A. Horstkotte 


\section{Abiotrophia defectiva endophthalmitis with retinal involvement and infiltrative keratitis - Case}

\section{report and review of the literature}

Matthias A. Horstkotte ${ }^{1 *} \equiv$, Sabine Dobinsky ${ }^{3}$, Holger Rohde ${ }^{1}$, Johannes K.-M. Knobloch ${ }^{4}$, Andrea Hassenstein $^{2}$, Matthias Kalitzky ${ }^{1}$, Gisbert Richard ${ }^{2}$, and Stephan J. Linke ${ }^{2 *}$

${ }^{1}$ Institut für Medizinische Mikrobiologie, Virologie und Hygiene, and ${ }^{2}$ Klinik und Poliklinik für Augenheilkunde, Universitätsklinikum Hamburg-Eppendorf, Martinistraße 52, 20246 Hamburg, Germany, ${ }^{3}$ DRK Kliniken Berlin, Westend, Spandauer Damm 130, 14050 Berlin, Germany, ${ }^{4}$ Institut für Medizinische Mikrobiologie und Hygiene, Universitätsklinikum Schleswig-Holstein, Campus Lübeck, Ratzeburger Allee 160, 23538 Lübeck, Germany, ${ }^{5}$ Laborärztliche Gemeinschaftspraxis Lübeck, Von-Morgen-Strasse 3, 23564 Lübeck, Germany

Keywords: Acute-onset postoperative endophthalmitis, retinal involvement, cataract surgery, Abiotrophia defectiva, nutritionally variant streptococci, 16S ribosomal RNA gene sequencing

* Corresponding authors: present address

D. Matthias A. Horstkotte

Dr. von Froreich - Bioscientia

Medizinisches Labor

Großmoorbogen 25

21079 Hamburg

Germany

Tel.: $\quad$ +49 40/76696117

FAX: + $4940 / 76696118$

E-mail: hor@labor-froreich.de
Dr. Stephan J. Linke

Klinik and Poliklinik für Augenheilkunde

Universitätsklinikum Hamburg-Eppendorf

Martinistraße 52

20246 Hamburg

Germany

Tel.: $\quad+4940 / 42803-3331$

FAX: $+4940 / 42803-4802$

E-mail: slinke@uke.uni-hamburg.de 


\begin{abstract}
We report the exceptional case of a severe intraocular Abiotrophia defectiva infection which developed after cataract surgery. Retinal involvement as a complication of A. defectiva endophthalmitis or the combination of acute-onset endophthalmitis with infiltrative keratitis caused by this pathogen has not been described. Moreover, our report represents the first documented ocular A. defectiva infection in Germany. A. defectiva was identified using biotyping and $16 \mathrm{~S}$ ribosomal RNA gene sequence analysis. Despite vigorous antimicrobial therapy and repeated ocular surgery visual outcome was poor.
\end{abstract}




\section{Introduction}

First described in 1961 nutritionally variant streptococci (NVS) [1] were initially considered to be mutants of viridans streptococcal strains. Today NVS are classified as A.defectiva and the related species Granulicatella adiacens, G. balaenopterae, and G. elegans [2]. With the exeption of $G$. balaenopterae which is only isolated from the minke whale [3] these pathogens colonize the human upper respiratory, urogenital, and gastrointestinal tract. On the other hand they are well recognized as important agent of both native and prosthetic valve endocarditis accounting for approximately $5 \%$ of cases [2-5]. Septicemia and bacteremia, especially in neutropenic patients or occurring postpartum and postabortal, have been reported less frequently. Further manifestations comprise central nervous system infections, vertebral osteomyelitis, pancreatic abscess, wound infections, and otitis media [13, 6, 7]. In contrast, ocular infections due to A. defectiva or Granulicatella species are very rare. We report on the first case of acute-onset postoperative endophthalmitis (AOPE) with retinal involvement due to A.defectiva. The infection was further complicated by the development of infiltrative keratitis despite vigorous antimicrobial therapy. The case represents the first description of an ocular A. defectiva infection in Germany. 


\section{Case report}

A 79-year-old female was admitted for acute endophthalmitis of her right eye three days after uneventful day-care cataract extraction and posterior chamber lens implantation. Preoperative prophylaxis was carried out with polymyxin $\mathrm{B}$, neomycin, and gramicidin containing eye drops for three days. On admission she complained of pain and blurred vision since one day. On examination, a severe fibrinous anterior chamber exsudate and hypopyon $(1 \mathrm{~mm})$ was found. Visual acuity was reduced to light perception. Cellular and protein deposits obscured funduscopy but a massive vitreous infiltration was confirmed by b-scan ultrasound. Apart from longstanding arterial hypertension the patients past medical and ocular history was unremarkable. There was no history of smoking or alcohol abuse nor signs and symptoms suggestive of impacting wound healing. Laboratory results were normal except leucocytes, $11.8 \times 10^{9} / \mathrm{l}$; and C-reactive protein, $11 \mathrm{mg} / \mathrm{l}$. Anterior chamber irrigation, standard 3 port vitrectomy and capsulotomy was carried out immediately showing extense white vitreous infiltration, predominantly of the anterior vitreous cavity. Specimens of the purulent aqueous and vitreous fluid were submitted for microbiological analysis. Intraoperatively, funduscopy revealed midperipheral preretinal bleedings and infectious infiltrations of the optic nerve head and the central retina. Antimicrobial therapy was started with intravitreal vancomycin and cefotaxime, anterior chamber irrigation with cefotaxime, subconjunctival gentamicin, topical ofloxacin and systemic imipenem and ciprofloxacin. To reduce the inflammatory reaction intravitreal dexamethason and postoperatively oral, subconjunctival and topical steroids were used. After an initial slight improvement the infection relapsed after four days with fibrinous membrane formation in the anterior chamber, hypopyon $(0.7 \mathrm{~mm})$ and severe cellular infiltration of the vitreous. Additionally, infiltrative keratitis had developed. A second surgical procedure with posterior chamber lens removal, cleavage of the fibrinous membrane, repeated standard 3 port vitrectomy, intravitreal cefotaxime and gentamicin, and subconjunctival gentamicin administration was performed. Subsequently, the endophthalmitis, inflammation of the anterior segment and the infiltrative keratitis resolved slowly. After ten days imipenem and ciprofloxacin were replaced by 
oral sultamicillin for another ten days. Three weeks after admission the media had almost cleared but

visual acuity was still reduced to hand movement. Funduscopy showed no retinal detachment but a persisting white infiltrate of the central retina and circular midperipheral preretinal bleedings (Figure 1A). Five months later the best corrected visual acuity was reduced to $20 / 400(+12.0$ aphacia correction). Funduscopy and fluorescein-angiography revealed pigment alterations of the macula and segmentally occluded retinal vessels (Figure 1B, 1C and 1D). Gram stain of the initial purulent anterior chamber aspirate revealed numerous leucocytes but no bacteria. After three days of aerobic incubation plus $5 \% \mathrm{CO}_{2}$ at $37{ }^{\circ} \mathrm{C}$ small, alpha-hemolytic colonies grew satelliting adjacent to crossstreaked Staphylococcus epidermidis on sheep blood supplemented (5\%) Columbia agar (Difco, Becton Dickinson, Sparks, Maryland, USA). The vitreous specimen yielded no growth. Catalase reaction was negative and upon Gram staining pleomorphic gram-positive cocci were seen. The rapid ID 32 Strept identification system (bioMérieux, Marcy l’Etoile, France) yielded low confidence for Streptococcus mitis (biocode 0202(6) 20(1)141 100, $52 \%$ ), A. defectiva (32\%) and S. sanguis (16\%) but the API 20 Strept gallery (bioMérieux) result was A. defectiva (biocode 1310051, $99 \%$ ). 16S ribosomal RNA gene sequencing using fD1-2 (5'CCGAATTCGTCGACAAGAGTTTGATCCTGGCTCAG-3') (Position 8-27 in Escherichia coli) and $\mathrm{rP2}$-L (5'-ACGGCTACCTTGTTACGACTT-3') (Position 1541-1517 in E. coli) as PCR primers and fD1-2 and rP2 (5'-GAATTACCGCGGCTGCTG-3') (Position 536-519 in E. coli) as sequencing primers [8] and BLAST analysis of the resulting sequence with known 16S ribosomal RNA gene sequences identified the isolate as A. defectiva with a maximal identity of $98 \%$ for A. defectiva strain 00394037, GenBank accession number AY879307. Next best taxon match was Granulicatella sp. oral clone ASCB09 with a maximal identity of $89 \%$. Using E-test (AB Biodisk, Solna, Sweden) on Isosensitest agar (Oxoid, CM 471) as recommended the strain was susceptible (minimal inhibitory concentrations in $\mu \mathrm{g} / \mathrm{ml})$ to penicillin $(0.064)$, sultamicillin $(\leq 0.016)$, cefotaxime (1), imipenem $(0.25)$, gentamicin (4), erythromycin (0.064), tetracycline (0.125), trimethoprim/sulfamethoxazole (0.008), ciprofloxacin (0.125), rifampin $(\leq 0.002)$, chloramphenicol (2), and vancomycin $(0.5)$. 


\section{Discussion}

AOPE is one of the most feared complications of ocular surgery. Like in our patient, AOPE typically presents a few days after cataract surgery with pain, hypopyon, vitreous opacification, and loss of vision. Fortunately, the incidence of AOPE has been reported to be as low as 0.05 to $0.20 \%$ [9]. Staphylococcus epidermidis is isolated most frequently (60\%) followed by S. aureus, streptococci, and enterococci (each 5-10\%) whereas gram-negative bacilli are found in only $6 \%$ [9]. We describe the first case of an acute-onset postoperative endophthalmitis (AOPE) with retinal involvement due to Abiotrophia defectiva. Infiltrative keratitis developed as a second complication despite potent antimicrobial therapy. Furthermore, the case represents the first reported ocular A. defectiva infection in Germany (Table 1). So far, only one intraocular A. defectiva infection has been described in the English literature [10]. Recently, two cases have been reported in a Spanish journal, which possibly delay the knowledge about these infections (Table 1) [11, 12]. In contrast to previous cases AOPE in our patient was complicated by retinal disease with involvement of the macula (cystoid macula edema) resulting in permanent severely reduced visual acuity. Additionally, infiltrative keratitis developed as a second complication despite potent antimicrobial therapy (Table 1). Very few patients suffering from A. defectiva keratitis $(\mathrm{n}=3)[3,13,14]$ or corneal ulcer $(\mathrm{n}=1)$ [3] have been described. The related species Granulicatella adiacens has been isolated in a single case of AOPE [10] and corneal ulcer [3], respectively. Older reports mentioned NVS in one case of endophthalmitis associated with filtering bleb surgery [15] and four cases of infectious crystalline keratopathy [16]. Additionally, corneal ulcers caused by Abiotrophia/Granulicatella organisms have been described in horses [16]. Even today reliable and rapid diagnosis of infectious endophthalmitis is challenging. Results of both aqueous and vitreous cultures are negative in 30 to $40 \%$ of patients with presumed bacterial endophthalmitis $[9,17]$. Paucity of organisms in the specimens and special growth requirements of the involved pathogens have been suggested as an explanation. Ocular A. defectiva or Granulicatella species infections may have been overlooked in particular as growth on standard culture media is variable $[2,3,5]$ and pyridoxal hydrochloride and L-cysteine supplementation or 
cross-streaking of the inoculated blood agar plates with staphylococci is necessary to negate the

nutritional defect [4]. However, we observed that sheep blood supplemented Schaedler agar served as an excellent culture medium. Further evaluation of this potential diagnostic improvement is warranted. Close phenotypic profiles with viridans streptococci, most notably Streptococcus mitis, and frequent unusual phenotypic characteristics render identification of A. defectiva tricky [3,5]. In accordance to our own results the rapid ID 32 Strept identification system (bioMérieux) has been reported to be less sensitive than the API 20 Strept gallery (bioMérieux) to correctly identify $A$. defectiva [2]. In contrast, 16S ribosomal RNA gene sequencing unambiguously identified our isolate as A. defectiva. The observed fulminant and complicated course AOPE and its slow resolution despite aggressive antimicrobial therapy and repeated surgical interventions highlight on the devastating nature of intraocular A. defectiva infections. The virulence of A. defectiva has been elucidated in bacterial endocarditis showing higher mortality rates, more frequent complications and the tendency to respond poorly to antibiotic therapy illustrated by greater bacteriologic failure and elevated relapse rates compared to endocarditis caused by other streptococci [4, 7]. Despite the lack of standardized testing methodology and interpretative criteria $A$. defectiva isolates were susceptible in vitro to vancomycin, rifampin, and chloramphenicol but variable rates of resistance or at least tolerance to penicillins and cephalosporins have been described $[4,7,18]$. Given the significant negative clinical impact, early recognition of A. defectiva as an emerging, potentially sight threatening pathogen appears mandatory. In contrast to controversies about antibiotic prophylaxis preoperative povidione-iodine had been the only procedure with proven benefit $[9,19,20]$. However, the significant reduction of AOPE by intracameral cefuroxime at the end of surgery and levofloxacin eye drops perioperatively have lead to a revision of the ESCRS guidelines [20]. Beside conjunctivitis, dacryocystitis, blepharitis and intraoperative complications (absent in our patient) clear corneal incision and silicon intraocular implants were identified as additional risk factors $[9,19,20]$. 


\section{References}

1. Frenkel A, Hirsch, W (1961) Spontaneous development of L forms of streptococci requiring secretions of other bacteria or sulphydryl compounds for normal growth. Nature 191:728-30

2. Ruoff KL (2007) Aerococcus, Abiotrophia, and other aerobic catalase-negative, gram-positive cocci. Murray PR, Baron EJ, Jorgensen JH, Landry ML, Pfaller MA (eds.), Manual of clinical microbiology, $9^{\text {th }}$ ed. ASM Press, Washington D.C., pp. 443-454

3. Christensen JJ, Facklam RR (2001) Granulicatella and Abiotrophia species from human clinical specimens. J Clin Microbiol 39:3520-3523

4. Johnson CC, Tunkel AR (2005) Viridans streptococci and groups C and G streptococci, and Gemella morbillorum. Mandell GL, Bennett JE, Dolin R (eds.) Mandell, Douglas, and Benett's principles and practice of infectious disease, sixth ed. Churchill Livingstone, Philadelphia, pp. $2434-2451$

5. Woo PCY, Fung AMY, Lau SKP, Chan BYL, Chiu SK, Teng JLL, Que TL, Yung RWH, Yuen KY (2003) Granulicatella adiacens and Abiotrophia defectiva bacteraemia characterized by 16S rRNA gene sequencing. J Med Microbiol 52: 137-140

6. Cerceo E, Christie JD, Nachamkin I, Lautenbach E (2004) Central nervous system infections due to Abiotrophia and Granulicatella species: an emerging challenge ? Diagn Microbiol Infect Dis 48:161-165

7. Murray CK, Walter EA, Crawford S, McElmeel ML, Jorgensen JH (2001) Abiotrophia bacteremia in a patient with neutropenic fever and antimicrobial susceptibility testing of Abiotrophia isolates. Clin Infect Dis 32:E140-142

8. Weisburg WG, Barns SM, Pelletier DA, Lane DL (1991) 16S ribosomal DNA amplification for phylogenetic study. J Bacteriol 173: 697-703

9. Hanscom TA (2004) Postoperative endophthalmitis. Clin Inf Dis 38:542-6

10. Namdari H, Kintner K, Jackson BA, Namdari S, Hughes JL, Peairs RR, Savage DJ (1999) Abiotrophia species as a cause of endophthalmitis following cataract extraction. J Clin 
Microbiol 37:1564-1566

11. Milagro AM, Moles B, Villuendas MC, Revillo MJ (2004) Endoftalmitis aguda tras extracción de catarata. Enferm Infecc Microbiol Clin 22:55-56

12. Esteban J, Montero-Sánchez R, Ortiz A, Yáñez F (2005) Endoftalmitis posquirúrgica debida a Abiotrophia defectiva. Enferm Infecc Microbiol Clin 23:455-456

13. Keay L, Harmis N, Corrigan K, Sweeney D, Willcox M (2000) Infiltrative keratitis associated with extended wear of hydrogel lenses and Abiotrophia defectiva. Cornea 19:864-869

14. Rudolph T, Welinder-Olsson C, Lind-Brandberg L, Stenevi U (2004) 16S rDNA PCR analysis of infectious keratitis: a case series. Acta Ophthalmol Scand 82:463-467

15. Lee K, Pien F (1993) Endophthalmitis caused by nutrient variant streptococci after filtering bleb surgery. Ann Ophthalmol 25:51-53

16. Ormerod LD, Ruoff KL, Meisler DM, Wasson PJ, Kintner JC, Dunn SP, Lass JH, van de Rijn I (1991) Infectious crystalline keratopathy - Role of nutritionally variant streptococci and other bacterial factors. Ophthalmology 98:159-169

17. Durand ML, (2005) Endophthalmitis, in Mandell, G. L., Bennett, J. E., Dolin, R., (Eds.): Mandell, Douglas, and Bennett's principles and practice of infectious disease, sixth ed. Churchill Livingstone, Philadelphia, pp. 1406-1413

18. Zheng X, Freeman AF, Villafranca J, Shortridge D, Beyer J, Kabat W, Dembkowski K, Shulman ST (2004) Antimicrobial susceptibilities of invasive pediatric Abiotrophia and Granulicatella isolates. J Clin Microbiol 42: 4323-4326

19. Soriano ES, Nishi M (2005) Endophthalmitis: incidence and prevention. Curr Opin Ophthalmol 16: 65-70

20. Endophthalmitis Study Group, European Society of Cataract \& Refractive Surgeons (2007) Prophylaxis of postoperative endophthalmitis following cataract surgery: results of the ESCRS multicenter study and identification of risk factors. J Cataract Refract Surg 33: 978-988 
Table 1: Reported cases of endophthalmitis due to Abiotrophia defectiva ${ }^{1}$

\begin{tabular}{|c|c|c|c|c|c|c|c|c|}
\hline \multirow[t]{2}{*}{ Age / Sex } & \multirow[t]{2}{*}{ Initial visual acuity } & \multirow[t]{2}{*}{ Complications } & \multicolumn{4}{|c|}{ Antimicrobial therapy } & \multirow[t]{2}{*}{ Outcome } & \multirow[t]{2}{*}{ Reference } \\
\hline & & & intraocular & subconjuntival & Topical & systemic & & \\
\hline $80 / \mathrm{F}^{2}$ & Hand movement & no & $\begin{array}{l}\text { Vancomycin } \\
+ \text { Ceftazidime }\end{array}$ & $\begin{array}{l}\text { Vancomycin } \\
+ \text { Ceftazidime }\end{array}$ & No & Ciprofloxacin & n..$^{3}$ & {$[10]$} \\
\hline $46 / F$ & Reduced & no & $\begin{array}{l}\text { Vancomycin } \\
+ \text { Amikacin }\end{array}$ & no & No & no & No sequelae & {$[11]$} \\
\hline $72 / \mathrm{M}^{4}$ & Loss of vision & no & $\begin{array}{l}\text { Vancomycin } \\
+ \text { Amikacin }\end{array}$ & no & $\begin{array}{l}\text { Vancomycin } \\
+ \text { Gentamicin }\end{array}$ & Vancomycin & Reduced visual acuity & {$[12]$} \\
\hline \multirow[t]{2}{*}{$79 / F$} & Light perception & $\begin{array}{l}\text { Retinal disease } \\
\text { Infiltrative } \\
\text { keratitis }\end{array}$ & $\begin{array}{l}{ }^{5} \text { Vancomycin } \\
+ \text { Cefotaxime }\end{array}$ & ${ }^{5}$ Gentamicin & Ofloxacin & $\begin{array}{l}\text { Imipenem } \\
+ \text { Ciprofloxacin }\end{array}$ & $\begin{array}{l}\text { Severely reduced } \\
\text { visual acuity (20/400) }\end{array}$ & Present report \\
\hline & & & $\begin{array}{l}{ }^{6} \text { Cefotaxime } \\
+ \text { Gentamicin }\end{array}$ & ${ }^{6}$ Gentamicin & & & & \\
\hline
\end{tabular}

${ }^{1}$ : All cases presented as acute-onset postoperative endophthalmitis two to ten days after cataract surgery with lens implantation.

${ }^{2}:$ female,${ }^{3}$ : not reported, ${ }^{4}:$ male $,{ }^{5}: 1^{\text {st }}$ ocular surgery, ${ }^{6}: 2^{\text {nd }}$ ocular surgery 


\section{Figure 1}

Despite an obscured retinal view funduscopy of the right eye (A) displayed a white infiltrate of the central retina (arrow) and circular midperipheral preretinal bleedings (arrowhead) three weeks after admission.

Five month later funduscopy (B) showed segmentally occluded retinal vessels (arrow). Fluorescein-angiography (C, before application of fluorescein; D, late phase) revealed pigment alterations of the macula but no signs of macula edema. 